\title{
Management Strategies of Mangrove Degradation in Coastal Areas of Brebes Regency, Central Java, Indonesia
}

Suyono Faperi*, Supriharyono², Ign Boedi Hendrarto² and Ocky Karna Radjasa²

${ }^{1 *}$ Doctoral Program of Coastal Resource Management, Diponegoro University, Indonesia

${ }^{2}$ Faculty of Fisheries and Marine Science, Diponegoro University, Indonesia

${ }^{3}$ National Institute of Oceanography, Douna Paula, Goa, India

\begin{abstract}
Issue on mangrove degradation and its impact viewed from ecological and anthropological aspects is constantly actual as it will reduce its vital function as a coastal protection from the danger of tsunami and abrasion, nutrient recycling, fisheries productivity biodiversity, dampening the rate of sea water intrusion and other coastal ecosystem crutches. This study aims to: determine the level of mangrove degradation; find out a model of mangrove area reduction dynamics due to the influence of ecological and anthropogenical factors including a model of perceptional correlation, to know community's perceptions and participation on mangrove degradation; then to further discover more effective strategies in dealing with coastal mangrove degradation in Brebes Regency coastal areas.
\end{abstract}

In the research areas, three species of mangrove vegetation were discovered in proper number; they were Rhizophora mucronata, Rhizophora apiculata and Avicennia marina. Overall, Rhizophora mucronata had the highest density of 35.731 ind./ha. in Kaliwlingi Village, Sub District of Brebes. Mangrove areas in Brebes Regency generally decreased with the reduction rate of 68,46 ha./year. Ecological and anthropogenical factors had the cohesion of the dynamics of a vast reduction in mangrove Brebes coastal areas. The value of natural growth factor $(99,60 \%)$, reforestation $(97,40 \%)$, death $(99,60 \%)$, logging $(99,60 \%)$, and abrasion $(99,60 \%)$. Most of the indicators of independent factors, perception and public participation factors showed a significant effect (valid) against the dependent factor (mangrove degradation) at $95 \%$ and $90 \%$ level of convidence, but the influence of ecological factors were more dominant than anthropogenical factor. The level of public perception had no effect on the level of participation.

The results showed that degradation of mangrove forests in Brebes Regency coastal areas were still allowed to be maintained and could be developed. The order of strategies to manage mangrove degradation in Brebes Regency coastal areas were: (1) Improving the protection of the mangrove areas from ocean waves/abrasion through anchoring/ more effective breakwater; (2) Increasing the empowerment of potential mangrove areas through productive activities that increase the added value for improving the welfare of local communities while preserving the mangrove; (3) Making the implementation of regulations and optimizing the role of relevant agencies, civil society organizations, and the participation of local communities in conserving mangrove areas and developing it; (4) Strengthening the institutional system of government and public institutions in the management of mangrove areas for short, medium and long term; and (5) Improving outreach activities/community related to the importance of mangroves for coastal resource conservation.

Keywords: Mangroves degradation; Coastal erosion; NDVI; Strategy

\section{Introduction}

Ecologically, mangroves ecosystem acts as a coastal protector of tsunami hazard and abrasion [1], nutrient recycling, fisheries productivity biodiversity, dampening the rate of sea water intrusion and other coastal ecosystems cantilever [2]. According to the Department of Marine and Fisheries Central Java Province [3], the Brebes Regency has 223.07 ha. mangrove areas, the widest in the region of western coast of Central Java with mangrove vegetation density categories sapling (seedling) 18.400 ind./ha., highest in Central Java Province. On the other side, mangroves in Brebes Regency have been degraded by abrasion and destruction by parties who are not responsible [4].

The interpretation of Landsat 7 TM satellite data dated May 31, 2013 from The National Aeronautics and Space Agency (LAPAN) using NDVI (Normalized Difference Vegetation Index) showed that the total area of mangroves in the coastal areas of Brebes Regency was only 243.20 ha., spreading over 26.56 ha. in Sub District of Losari, 5.60 ha. in Subdistrict of Tanjung, $35.42 \mathrm{ha}$. in Sub District of Bulakamba, 14.31 ha. in Sub District of Wanasari and 161.31 ha. in Sub District of Brebes.

The degradation of mangrove leads to abrasion and otherwise decreases the quantity and quality of coastal resources including mangroves itself $[5,6]$. The linkage between ecological and anthropoginical factors in mangrove degradation and abrasion can not be ignored [7]. Improvement efforts for the ecosystem have been done with no provided significant results. In this regard, this study was determined: to analysis the level of mangrove degradation; to find out a correlation of mangrove area reduction due to the influence of ecological and anthropogenical factors; correlation of community perceptions and participation in mangrove degradation; then to discover more effective strategies in dealing with mangrove degradation in Brebes Regency coastal areas.

*Corresponding author: Suyono Faperi, Doctoral Program of Coastal Resource Management, Diponegoro University, Imam Bardjo, S.H. Street, No. 5 Semarang, Indonesia, E-mail: suyono.faperi.ups@gmail.com

Received January 26, 2015; Accepted April 10, 2015; Published April 20, 2015

Citation: Faperi S, haryono S, Hendrarto IB, Radjasa OK .(2015) Management Strategies of Mangrove Degradationin Coastal Areas of Brebes Regency, Central Java, Indonesia. J Coast Zone Manag 18: 401. doi: 10.4172/2473-3350.1000401

Copyright: $\odot 2015$ Faperi S, et al. This is an open-access article distributed under the terms of the Creative Commons Attribution License, which permits unrestricted use, distribution, and reproduction in any medium, provided the original author and source are credited. 
Citation: Faperi S, haryono S, Hendrarto IB, Radjasa OK .(2015) Management Strategies of Mangrove Degradationin Coastal Areas of Brebes Regency, Central Java, Indonesia. J Coast Zone Manag 18: 401. doi: 10.4172/2473-3350.1000401

\section{Materials and Methods}

\section{Study sites}

This research was conducted in the coastal areas of Brebes Regency, Central Java for 7 months from May - November 2013. Stations of observation are determined purposively based on area having mangrove forests, among others : Losari Sub District (Karangdempel Village), Tanjung (Krakahan Village), Bulakamba (Grinting Village), Wanasari (Sawojajar Village), and Brebes (Kaliwlingi and East Randusanga Villages) as presented in Figure 1.

\section{Data collection}

Data of mangrove areas and conditions from Landsat TM satellite image dated May 31, 2013 by the National Aeronautics and Space Agency was processed with GIS technology (Geographic Information System) and then field check was performed. Landsat image imposed data format conversion, image choise, classification, analysis of mangrove vegetation index with Normalized Difference Vegetation Index (NDVI). Data Collection of mangrove vegetation was conducted using transects along $100 \mathrm{~m}$ and width of $20 \mathrm{~m}$. In a transect of station of observations a $10 \mathrm{~m}$ $\times 10 \mathrm{~m}$ graded plots are made for trees category, $5 \mathrm{~m} \times 5 \mathrm{~m}$ for saplings, and $1 \mathrm{~m} \times 1 \mathrm{~m}$ for the seedlings, and then all of types and quantities of mangrove vegetation in the plot area are recorded [8].

\section{Data analysis}

Data calculating is done by using Microsoft Excel. It consists of calculating the density of mangrove species, type frequency, closing of type relative and importance value index of mangrove [9]. Analysis on dynamic systems of ecological factor is done with Power Sim 2.0 software as stated by [10]. To determine the inter-relationship between the public perception and participation towards the mangroves degradation is done with Structural Equation Modeling (SEM) using LISREL 8.80 program as recommended by [11]. Determination of the more effective policy in handling of mangrove degradation is done through two stages of analysis: SWOT (Strenghts, Weakness, Opportunity, Threat) and AHP (Analytical Hierarchy Process) using Expert Choise V.9 program as recommended from $[12,13]$.

\section{Results and Discussion}

\section{Mangrove ecological conditions}

Mangrove area changes and mangrove vegetation conditions: Brebes Regency coastal areas are along $65.480 \mathrm{~km}$. Mangrove areas changes in Brebes Regency coastal areas from 1983 to 2013 as presented in Table 1.

Decline in mangrove area is due to changes in the coastline as a result of abrasion, accretion and mangrove community structure $[14,15]$. It can be seen from type of density, frequency, closure and the importance value index of each mangrove vegetation type [16] as presented in Table 2 .

Species density and mangrove forest area: The highest density for this species of Rhizophora mucronata was found at station 5 (35.731 ind./ha.) and the lowest at station 1 (10.162 ind./ha.). The highest density for Rhizophora apiculata, was found at station 6 (420 ind./ha.), and relative was not found at stations 3 and 4 . The highest density of Avicennia marina was at station 5 (500 ind./ha.) and was not found at station 4. Relatively high densities was at Station 5 (Kaliwlingi, Sub District of Brebes) as a result of mangrove reforestation activity at the site, especially species of $R$. mucronata mangrove vegetation which had resulted in the category of trees and saplings beside the still form of a nursery. The greater of density values shows a good mangroves condition, the lower the number shows the threat of mangrove degradated.

Analysis of normalized difference vegetation index (NDVI): Mangrove density, according to satellite imagery, can be seen from the results of the analysis using the Normalized Difference Vegetation Index (NDVI), which can separate the vegetation objects with nonvegetation. To distinguish between mangrove vegetation and other vegetation is to look at the vegetation distance to the beach. In this study the distance was as far as 200 meters in accordance with Decree of Minister of Agriculture and Minister of Forestry No. KB.550 / 264 / kpts / 4/1984 and No. 082 / Kpts-H / 1984, dated 30 April 1984 which claimed wide green belt of mangrove forests is 200 meters. Vegetation found around the coast is assumed as mangrove vegetation. From the

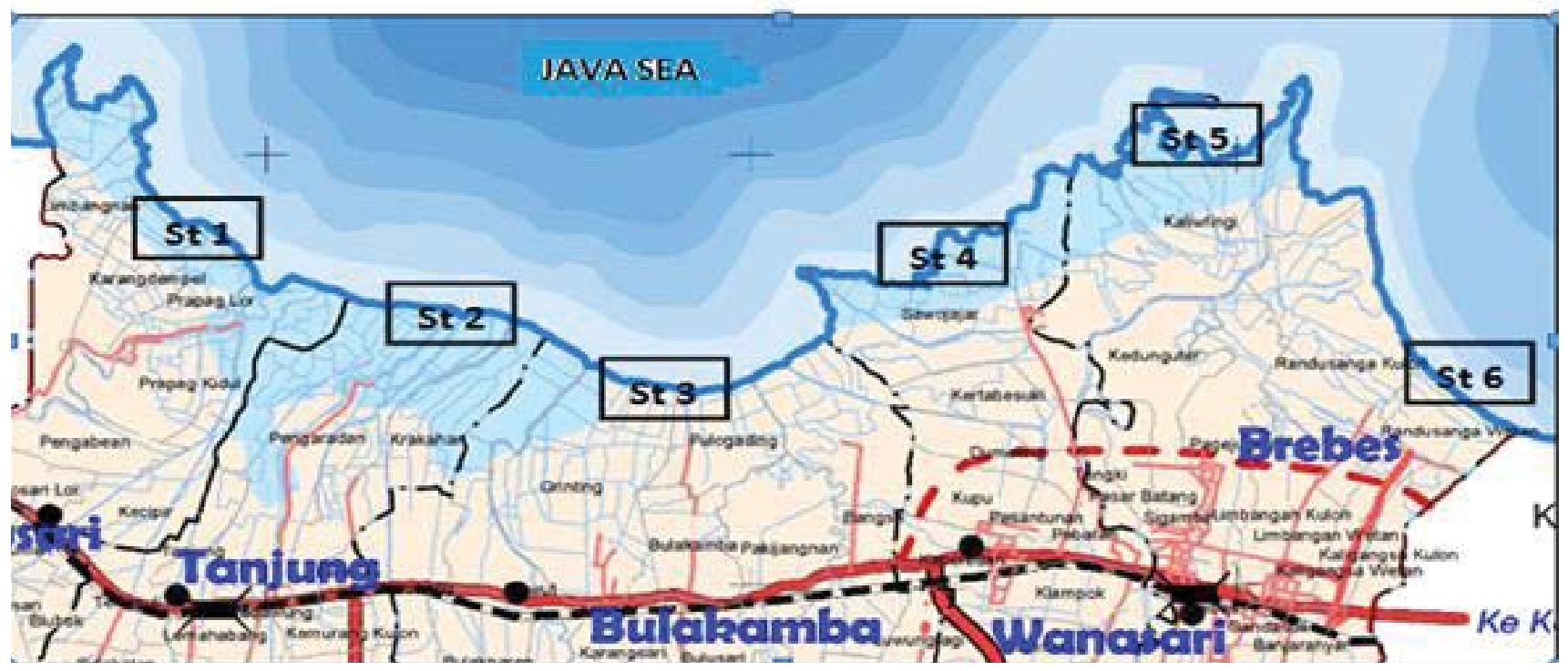

Figure 1: Location of research observation station 
Citation: Faperi S, haryono S, Hendrarto IB, Radjasa OK .(2015) Management Strategies of Mangrove Degradationin Coastal Areas of Brebes Regency, Central Java, Indonesia. J Coast Zone Manag 18: 401. doi: 10.4172/2473-3350.1000401

Page 3 of 12

\begin{tabular}{|c|c|c|c|c|c|c|c|c|c|}
\hline \multirow{2}{*}{ No } & \multirow{2}{*}{ Sub District } & \multicolumn{7}{|c|}{ Mangrove area (ha.) } \\
\cline { 3 - 10 } & & $\mathbf{1 9 8 3}$ & $\mathbf{2 0 0 0}$ & $\mathbf{2 0 0 2}$ & $\mathbf{2 0 0 8}$ & $\mathbf{2 0 1 0}$ & $\mathbf{2 0 1 1}$ & $\mathbf{2 0 1 3}$ \\
\hline 1 & Losari & -- & -- & 46,26 & 52,63 & 39,00 & 30,24 & 26,56 \\
\hline 2 & Tanjung & -- & -- & 25,56 & 18,97 & 5,00 & 7,50 & 5,60 \\
\hline 3 & Bulakamba & -- & -- & 31,95 & 39,55 & 59,00 & 47,23 & 35,42 \\
\hline 4 & Wanasari & -- & -- & 48,06 & 27,29 & 37,00 & 18,57 & 14,31 \\
\hline 5 & Brebes & -- & -- & 94,41 & 145,89 & 134,00 & 154,50 & 161,31 \\
\hline & & 2327 & 505,00 & 246,24 & 284,31 & 274,00 & 258,04 & 243,20 \\
\hline
\end{tabular}

Source: Agency for the Assessment and Application of Technology (2001), Brebes Regency Environment Office (2003), Department of Fisheries and Marine Brebes Regency (2008), Agency of Region Development and Planning, Central Java Province (2012) and the results of the study (2013)

Table 1: Change of mangrove areas in Brebes Regency.

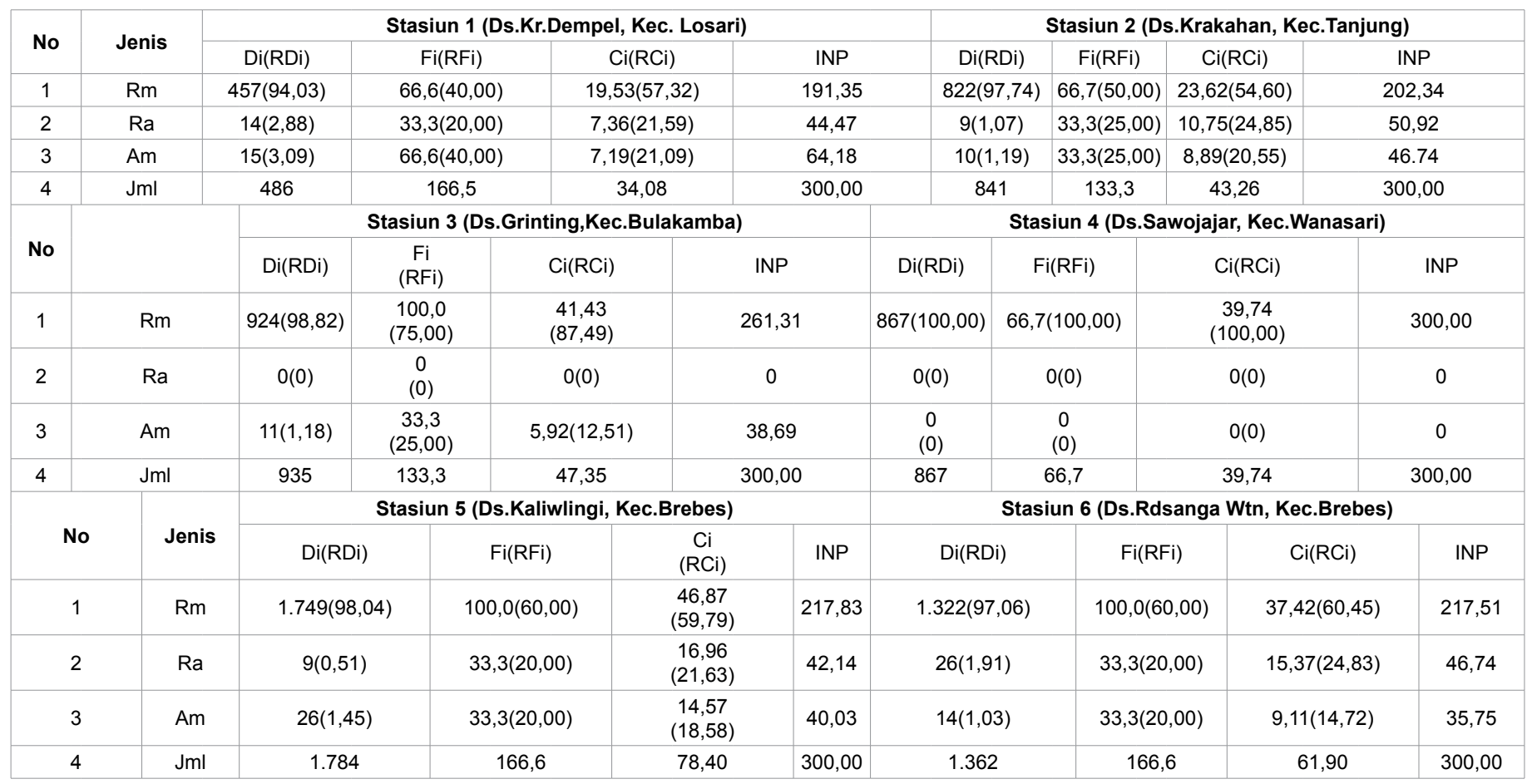

Source: Results of the study (2013). Description : Rm: Rhizophora mucronata, Ra : Rhizophora apiculata, Am : Avicennia marina

Table 2: Density ( $\mathrm{Di}$, ind./ha.), type frequency $(\mathrm{Fi}, \%)$, type closure $\left(\mathrm{Ci}, \mathrm{m}^{2} / 100 \mathrm{~m}^{2}\right)$, relative density $(\mathrm{RDi}, \%)$, relative frequency $(\mathrm{RFi}, \%)$, relative closure $(\mathrm{RCi}, \%)$ and important value index (IVI, \%) of mangrove vegetation in Brebes Regency coastal areas.

analysis using NDVI in Brebes Regency coastal areas, it is obtained 4 groups of mangrove vegetation density. The greatest mangrove area is rarely density, that is $80.34 \mathrm{ha}$. and the smallest is mangrove vegetation densities in tightly, that is 29.16 ha. Along Brebes Regency coastal area, the mangrove area with very density categories was not found as presented in Table 3.

In general, the density of mangrove was proportional to NDVI values as presented in Table 4. Mangrove area in the Sub District of Brebes beach was the widest for all density categories.

Frequency of mangrove vegetation types (Fi): Frequency value indicates chance discovery of a particular species on the plot in the observation station [9]. R. mucronata has Fi value of 1.00, the highest frequency of observation is at stations 3, 5 and 6 respectively in Bulakamba sub district and Brebes sub district (Kaliwlingi and Randusanga Wetan villages), which means that species is found in all plots. R. apiculata at stations 3 and 4 in Bulakamba and Wanasari sub districts and A. marina at stations 1 and 4 in Losari and Wanasari sub districts have Fi of 0 (it's not found in all plots observation stations).
At station 1, 2 and 4, respectively in Losari, Tanjung and Wanasari sub districts, $R$. mucronata has Fi value of 0.6667 which means it is found in two of three plots observation stations. R. apiculata at station 1, 2, 5 and 6 respectively in Sub District of Losari, Tanjung, and Brebes (Kaliwlingi and Randusanga Wetan villages). and A. marina at stations 2, 3, 5 and 6 respectively in Sub District of Tanjung, Bulakamba, Brebes (Kaliwlingi and Randusanga Wetan villages) have Fi value of 0.3333 , which means it is only found on one plot of three plots in the observation station.

Species closure of mangrove vegetation (Ci): The closure of mangrove species is the widespread of mangrove stem/basal in a particular area. It can also be described from the stand diameter of mangrove vegetation. $R$. mucronata has the highest closure value of 11,60 at station 5 in Kaliwlingi Village Sub District of Brebes. On the other hand, R. apiculata at observation stations 3 and 4 in Bulakamba and Wanasari sub districts, and A. marina at observation stations 4 in the Sub District of Wanasari have closure value of 0 .

Important value index (IVI): Important Value Index (IVI) shows the existence of a role or influence of mangrove vegetation types in 
Citation: Faperi S, haryono S, Hendrarto IB, Radjasa OK .(2015) Management Strategies of Mangrove Degradationin Coastal Areas of Brebes Regency, Central Java, Indonesia. J Coast Zone Manag 18: 401. doi: 10.4172/2473-3350.1000401

Page 4 of 12

\begin{tabular}{|c|c|c|c|c|c|c|}
\hline \multirow[b]{2}{*}{ No } & \multirow[b]{2}{*}{ Sub District } & \multicolumn{5}{|c|}{ Mangrove area (ha.) } \\
\hline & & $\begin{array}{c}\text { Very rare,badly } \\
\text { damaged }\end{array}$ & Rarely,Damaged & Medium,moderated & Tightly,good & Total \\
\hline 1 & Losari & 6,50 & 9,14 & 7,80 & 3,12 & 26,56 \\
\hline 2 & Tanjung & 1,50 & 2,15 & 1,25 & 0,70 & 5,60 \\
\hline 3 & Bulakamba & 7,70 & 10,22 & 12,25 & 5,25 & 35,42 \\
\hline 4 & Wanasari & 4.85 & 5.39 & 3.30 & 0,77 & 14,31 \\
\hline 5 & Brebes & 40,25 & 53,44 & 48,30 & 19,32 & 161,31 \\
\hline 6 & Jumlah & 60,80 & 80,34 & 72,90 & 29,16 & 243,20 \\
\hline
\end{tabular}

Source: Results of the study (2013); Decree of Environment Minister No.201, 2004.

Table 3: Mangrove areas based on density levels.

\begin{tabular}{|c|c|c|c|c|c|}
\hline Station & $\begin{array}{c}\text { Village } \\
\text { (Sub District) }\end{array}$ & $\begin{array}{c}\text { Mangrove density (ind.I } \\
\text { ha.) }\end{array}$ & NDVI & $\begin{array}{c}\text { Category } \\
\text { Degradation }\end{array}$ & Density \\
\hline 1 & Kr.Dempel (Losari) & 486 & 0,096367 & Badly damaged \\
\hline 2 & Krakahan (Tanjung) & 841 & 0,173824 & Ramaged \\
\hline 3 & Grinting (Bulakamba) & 935 & 0,165197 & Rarely \\
\hline 4 & Sawojajar (Wanasari) & 867 & 0,116388 & Ramaged \\
\hline 5 & Klwlingi (Brebes) & 1.784 & 0,341315 & Damaged \\
\hline 6 & RdsangaWtn (Brebes) & 1.362 & 0,253568 & Tightly \\
\hline
\end{tabular}

Source: Results of the study (2013); Decrre of Environment Ministry No 201, 2004.

Table 4: Density of mangrove and its NDVI value on the image for each station.

the community with a range of 1-300. Generally, $R$. mucronata has the largest IVI at all stations. Classification to see the important role of each type of mangrove in the community is: $0 \leq \mathrm{INP}<100$ : low; $100 \leq$ INP > 204.31: medium and 204.3I $\leq$ INP $\leq 300$ : height. Based on the classification, it can be explained that the station having a low function toward the community are: R. apiculata and R. Mucronata. In almost all stations, A. marina has a high role, except at station 1 in Losari Sub District which the IVI has its medium categorized. Of all the existing stations, $R$. mucronata at station 4 in Wanasari Sub District has the highest IVI with a value of 300 . The lowest value of $R$. apiculata are at stations 3 and 4 in Bulakamba and Wanasarisub districts, and $A$. marina at station 4 in the Wanasari Sub District with a IVI value of 0.

Dynamic system analysis of mangrove areas changes in brebes regency: The dynamics of mangrove areas changing in Brebes Regency coastal regions are presented in Table 5.

From the data obtained, structured dynamic model of ecological processes and anthropogenic affects mangrove vegetation in Brebes Regency coastal areas as presented in Figure 2.

The change in the mangrove area is affected by the addition of mangrove due to naturally growth factors and reforestation, besides; reduction is due to coastal abrasion and logging of mangrove forests [17-19]. From the simulation it is known the rate of mangrove degradation in Brebes Regency following equality $\mathrm{Y}=2327+0.039$ $\mathrm{X} 1+0.087 \mathrm{X} 2-0,021 \mathrm{X} 3-0,071 \mathrm{X} 4-0.118 \mathrm{X} 5$, where Y (mangrove areas in Brebes Regency); 2327 (extent of mangroves in Brebes coastal area at the beginning of the calculation, 1983); X1 (addition of mangrove vegetation naturally growth factors); X2 (addition of mangrove vegetation reforestation factors); X3 (mangrove vegetation reduction because of death); X4 (reduction of mangrove vegetation due to logging/burning); and X5 (reduction of mangrove vegetation due to abrasion). Mangrove reforestation effort that has been done can increase the number of mangrove vegetation with an average of 17.82 ha./year, but it has decreased at a rate of 68.46 ha./year, where abrasion, logging and other natural causes of death each providing contribution $56 \%, 34 \%$ and $10 \%$.

Perceptions and public participation: Perception and participation value of coastal communities about the condition and management of mangroves in Brebes coastal areas are presented in Table 6.

Public perception of mangrove importance is in the range of moderate to very good with an average value of 4.19 (good). The perception was not followed by commensurate participation of 3.76 (medium) as presented in Figure 3. The average of mangrove degradation is in level of 3.50 (moderate).

Analysis of SEM (Structural Equation Modeling): Correlation model of perception, participation and mangrove degradation in Brebes Regency using SEM (Structural Equation Modeling) Lisrel 8.80 follow [20] is presented in Figure 4.

The results of processing by using SEM program Lisrel 8.80 [20] produces an equation that shows the relationship between variables in the model is modified, as follows: LISREL Estimates (Maximum Likelihood), Structural Equations :

PARTISIP $=13.53+0.090^{*}$ PERSEPSI, Errorvar. $=0.31, \mathrm{R}^{2}=0.54$

$$
\begin{array}{ll}
(0.88) & (0.052) \\
15.39 & 1.75
\end{array}
$$

MANGROVE $=17.78-0.14^{\star}$ PARTISIP, Errorvar. $=0.36, \mathrm{R}^{2}=0.52$

$$
\begin{array}{lll}
(1.44) & (0.084) & (0.054) \\
12.37 & -1.61 & -1.87
\end{array}
$$

These equations can be described as follows:

1. Estimation of the standard error (second row numbers in each equation) is worth less than the coefficient of the equation so that it can be stated that the estimated parameters are relatively precise appear.

2. Most of the independent factors show a significant effect (valid) toward the dependent factor influenced at $90-95 \%$ confidence level. It is shown by the indicator validity ( $t$ value, the numbers on the $3 \mathrm{rd}$ line in each equation which is the ratio between the value of the regression coefficient estimates the error standard) is more than the table value of $\mathrm{t}$ table $0.10 \mathrm{t}=1.60$ and some more than $\mathrm{t}$ table $0.05=1.96$.

3. On the other hand, the value of reliability $\left(R^{2}\right)$ states how much the proportion of variance explained by the latent variable indicator 
Citation: Faperi S, haryono S, Hendrarto IB, Radjasa OK .(2015) Management Strategies of Mangrove Degradationin Coastal Areas of Brebes Regency, Central Java, Indonesia. J Coast Zone Manag 18: 401. doi: 10.4172/2473-3350.1000401

\begin{tabular}{|c|c|c|c|c|c|c|c|}
\hline \multirow{2}{*}{ No } & \multirow{2}{*}{ Year } & \multicolumn{6}{|c|}{ Mangrove area (ha.) } \\
\hline & & Growth & Reforestation & Death & Logging & Abrasion & End conditions \\
\hline 1 & 1983 & 92 & 86 & 48 & 163 & 276 & 2327 \\
\hline 2 & 2000 & 18 & 37 & 9 & 33 & 55 & 505 \\
\hline 3 & 2002 & 16 & 34 & 8 & 29 & 50 & 246 \\
\hline 4 & 2008 & 12 & 25 & 6 & 21 & 37 & 284 \\
\hline 5 & 2010 & 11 & 22 & 5 & 19 & 33 & 274 \\
\hline 6 & 2011 & 10 & 21 & 5 & 18 & 31 & 258 \\
\hline 7 & 2013 & 9 & 19 & 5 & 17 & 28 & 243 \\
\hline
\end{tabular}

Source: Agency for Assessment and Application of Technology (2001), Brebes Regency Environment Office (2003), Department of Fisheries and Marine Regency of Brebes Regency (2008), Agency of Region Development and Planning, Central Java Province (2012), and the research results were processed (2013). Table 5: The dynamics of mangrove areas changing in Brebes Regency coastal areas.
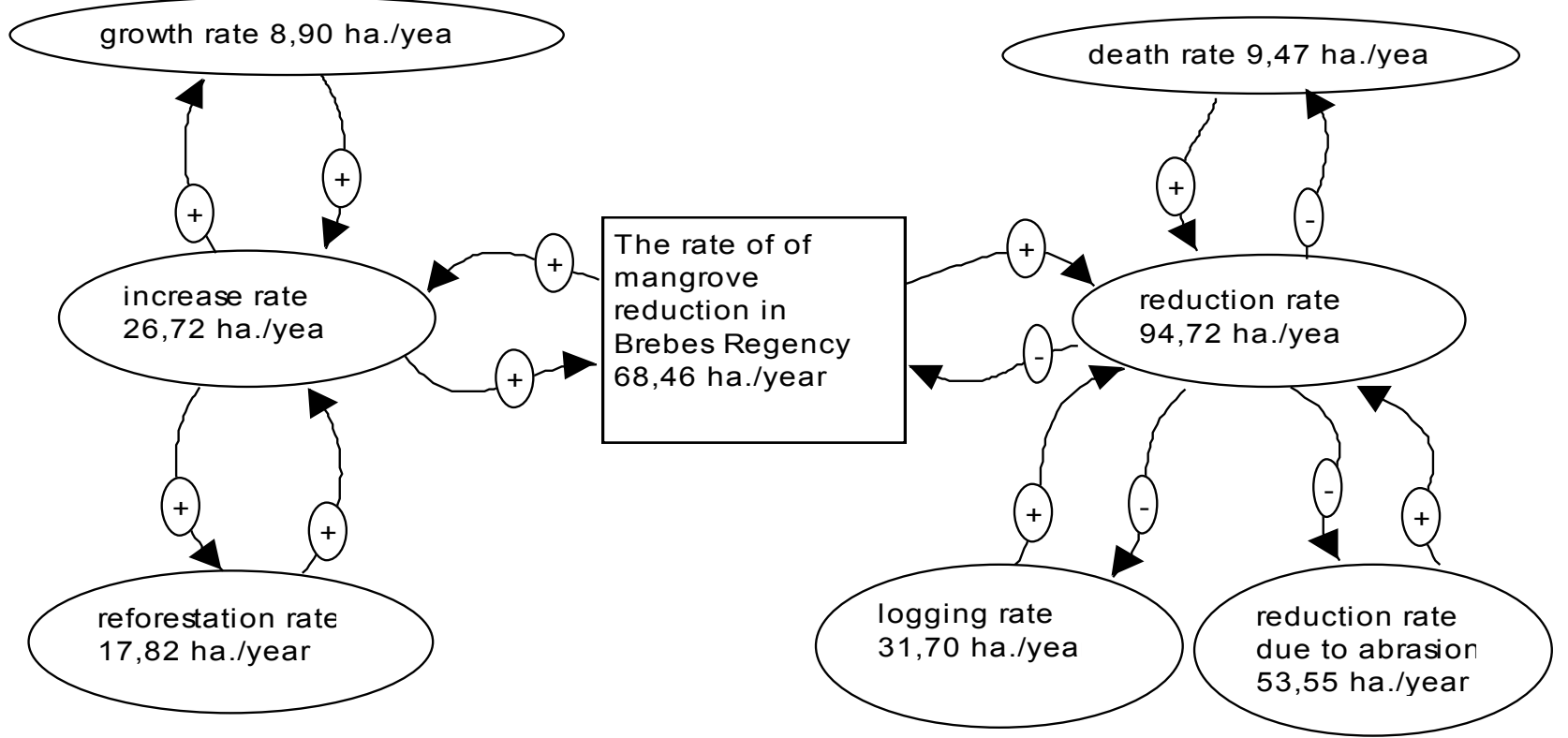

Figure 2: The average rate of mangrove areas change in Brebes Regency.

(while the rest is explained by the value of the size of the error) generally shows a relatively small number so it can be stated that the effect of logging/burning mangroves contributes relatively little impact on the dynamics of a vast reduction in Brebes Regency mangrove areas. The more significant factors that play a role in the reduction of Brebes Regency mangrove area are indicated by the relatively large error value and in this case alleged an ecological factor, that is abrasion.

Rehabilitation of mangrove forests: Mangrove rehabilitation activities in Brebes coastal areas have been being done since 2004 . Until December 2004, mangrove vegetation had been done along Brebes Regency coastal areas covering 500 ha. The land that had been replanted consists of an area of 325 ha. and a stretch of dike embankment measuring 175 ha. in 13 villages in five sub districts in Brebes Regency coastal area [21]. R. mucronata was planted at a spacing of $1 \mathrm{~m} \mathrm{x} \mathrm{lm}$. One hectare of land was planted with $2000 \pm R$. mucronata seedling stems. According to [22,23], associated with physical function as wave absorbers that has pounded the coast and biological function as a habitat for marine life, the rehabilitation of mangrove areas directly facing the sea as green belt becomes very important. Based on satellite imagery delineation results May 31, 2013, it is obtained that the length of Brebes Regency coastline is $56.68 \mathrm{~km}$. By decree of the Minister of Agriculture and Minister of Forestry No. KB.550/264/kpts/4/1984 and No.082/Kpts-H/1984, dated 30 April 1984, the width of mangrove forest green belt is 200 meters, so Brebes coastal region should have an area of mangrove forest belt $113.36 \mathrm{~km}^{2}$ or $1.133 .60 \mathrm{ha}$. The area of mangrove forests in Brebes coastal region based on analysis of Landsat TM dated May 31, 2013 is amounted to 243.20 ha. and results of rehabilitation activities undertaken since 2004 is 746.24 ha, so it is necessary to increase mangrove rehabilitation area of 387.36 ha. again.

The utilization of Brebes coastal area in 2012 focused on mangrove reforestation in Sub District of Wanasari, Bulakamba and Tanjung. The area of mangrove reforestation proposal were three regions: in the mouth of Cisanggarung river in Losari Sub District, estuary of Kluwut river in Bulakamba Sub District, and eastern of Pemali river estuary in Brebes Sub District. Mangrove rehabilitation to restore ecological and economical functions needs to consider supporting and inhibiting factors, including the election of mangrove vegetation species according to the type of soil beaches [24]. Based on the type of substrate and the condition of the beach (abrasion and accretion), the mangrove vegetation that can be planted are species of Rhizophora spp. 
Citation: Faperi S, haryono S, Hendrarto IB, Radjasa OK .(2015) Management Strategies of Mangrove Degradationin Coastal Areas of Brebes Regency, Central Java, Indonesia. J Coast Zone Manag 18: 401. doi: 10.4172/2473-3350.1000401

\begin{tabular}{|c|c|c|c|c|c|}
\hline \multirow{2}{*}{ Perception } & \multicolumn{4}{|c|}{ The average value of question: } & \multirow{2}{*}{$\begin{array}{l}\text { Number } \\
\text { (average) }\end{array}$} \\
\hline & 1 & 2 & 3 & 4 & \\
\hline $\begin{array}{c}\text { The average value of West } \\
\text { Brebes region }\end{array}$ & 4,36 & 4,38 & 3,84 & 4,24 & $16,82(4,20)$ \\
\hline $\begin{array}{l}\text { The average value of } \\
\text { Central Brebes region }\end{array}$ & 4,16 & 4,10 & 3,94 & 3,96 & $16,16(4,04)$ \\
\hline $\begin{array}{c}\text { The average value of East } \\
\text { Brebes region }\end{array}$ & 4,52 & 4,52 & 3,98 & 4,36 & $17,38(4,34)$ \\
\hline $\begin{array}{l}\text { The average value of } \\
\text { overall Brebes region }\end{array}$ & 4,34 & 4,33 & 3,92 & 4,18 & $16,78(4,19)$ \\
\hline
\end{tabular}

Source: Results of the study (2013) Specification: Value 1: Strongly disagree; not very good; Value 2: Do not agree; not good; Value 3: Hesitation; moderate; Value 4: Agree; good; Value 5: Strongly agree; very good

\begin{tabular}{|c|c|c|c|c|c|}
\hline \multirow{2}{*}{ B. Participation } & \multicolumn{4}{|c|}{ The average value of question: } & \multirow{2}{*}{$\begin{array}{c}\text { Number } \\
\text { (average) }\end{array}$} \\
\hline & 1 & 2 & 3 & 4 & \\
\hline The average value of West Brebes region & 4,20 & 3,84 & 3,60 & 3,58 & $15,22(3,80)$ \\
\hline The average value of Central Brebes region & 3,56 & 3,62 & 3,42 & 3,32 & $13,92(3,48)$ \\
\hline The average value of East Brebes region & 4,40 & 4,08 & 3,78 & 3,78 & $16,04(4,01)$ \\
\hline The average value of overall Brebes region & 4,05 & 3,84 & 3,60 & 3,56 & $15,06(3,76)$ \\
\hline
\end{tabular}

Source: Results of the study (2013) Specification: Value 1: It's not often; never at all, not very good; Value 2: Not often; $1-2$ times per year or once of 5 activities, not good Value 3: Mean; 3-6 months or once from 3-4 activities, moderate; Value 4: Often; once a month or once of twice the activity, good; Value 5: Very often; more than 1 time a month or on each activity, very good.

\begin{tabular}{|c|c|c|c|c|c|}
\hline \multirow{2}{*}{ C. Mangrove degradation } & \multicolumn{4}{|c|}{ The average value of question : } & \multirow{2}{*}{$\begin{array}{l}\text { Number } \\
\text { (average) }\end{array}$} \\
\hline & 1 & 2 & 3 & 4 & \\
\hline The average value of West Brebes region & 3,82 & 3,30 & 3,14 & 3,58 & $13,84(3,46)$ \\
\hline The average value of Central Brebes region & 3,86 & 3,36 & 3,44 & 3,12 & $13,78(3,44)$ \\
\hline The average value of East Brebes region & 4,00 & 3,46 & 3,26 & 3,70 & $14,42(3,60)$ \\
\hline The average value of overall Brebes region & 3,89 & 3,37 & 3,28 & 3,46 & $14,01(3,50)$ \\
\hline
\end{tabular}

Source: Results of the study (2013) Specification: Value 1: It's not very serious; degradated to $0 \%$, the rapid growth of mangrove (score 1); Value 2: not serious; level of degradated $<10 \%$, mangroves continue to grow normally, there is the addition of mangroves (score 2); Value 3 : slightly degradated; the level of mangrove degradation 10 to $<25 \%$, there is an addition/mangrove growth (score 3); Value 4 : serious; level of mangrove degradation 25 to $<75 \%$, relative to no addition/ mangrove growth (score of 4); Value 5 : very serious; very degradated, $\geq 75 \%$, no additional and mangrove growth (score 5 )

Table 6: Perception and participation value of coastal communities about the condition and management of mangrove in Brebes Regency. A. Perception, B. Participation C. The rate of mangrove degradation.
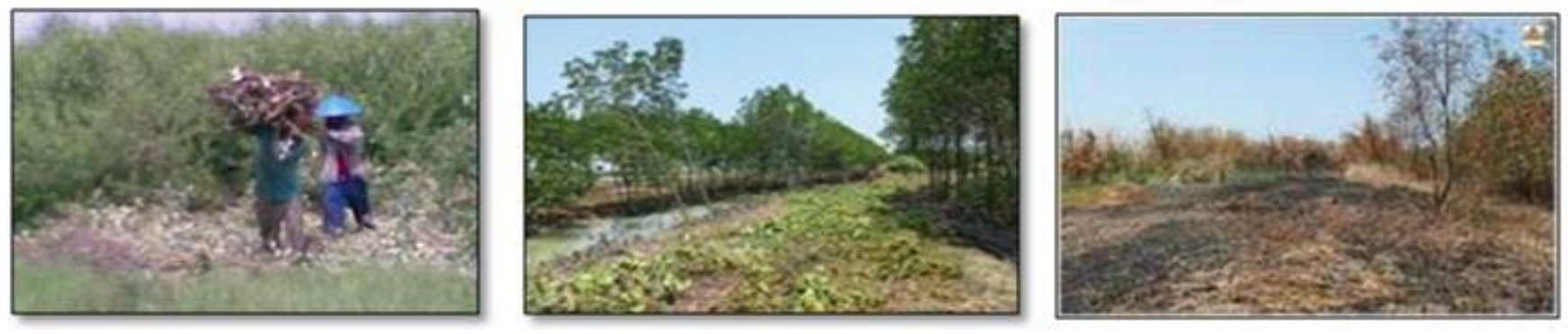

Figure 3: Illegal logging and burning of mangrove by community in Brebes Regency.

and Avicennia spp. for mangrove rehabilitation activities in Sub District of Losari until Wanasari, meanwhile around the estuary of Pemali River Rhizophora spp. can be planted. According to Bengen [9], mangrove species planted for retaining abrasion is Rhizophora spp. and for greening is Avicennia spp. Planting Rhizophora spp. in Brebes Regency coastal areas can be done by tying profagul (mangrove seeds) to 'ijiran'. Ijiran is a place profagul (mangrove seeds) attached, in the form of four split bamboo with a diameter of $2.5 \mathrm{~cm}$, a length of $1.5 \mathrm{~m}$ and a weight of $0.25 \mathrm{~kg}$ which is plugged into the subgrade coastal waters as deep as 50-75 cm as shown in Figure 5. In some observation stations 'ijiran' are seen collapsed by ocean waves. This is likely due to the lack of proper site selection and embedding depth of ijiran that is less than optimal. To obtain a balance between the power of mangrove vegetation planted and power surge that has pounded the coast, the amount of potential energy of mangrove vegetation planted must be equal to the power per meter wave front [25].

The highest value in the third observation station is $1.07 \mathrm{~m}$ so ijiran should be plugged into the subgrade coastal waters at least as deep as $1.07 \mathrm{~m}$ against buckling by the waves of the sea. To streamline the reforestation, it requires the protective building of new mangrove vegetation planted on the ocean wave action. The making of the building should consider the causes of abrasion particularly the direction and strength of currents/waves which fit the pattern of sediments cell formation [26,27]. The building of a breakwater made of bamboo materials in Kaliwlingi beach enable to survive long enough are presented in Figure 6.

The breakwater building of bamboo materials in Karang Dempel 
Citation: Faperi S, haryono S, Hendrarto IB, Radjasa OK .(2015) Management Strategies of Mangrove Degradationin Coastal Areas of Brebes Regency, Central Java, Indonesia. J Coast Zone Manag 18: 401. doi: 10.4172/2473-3350.1000401

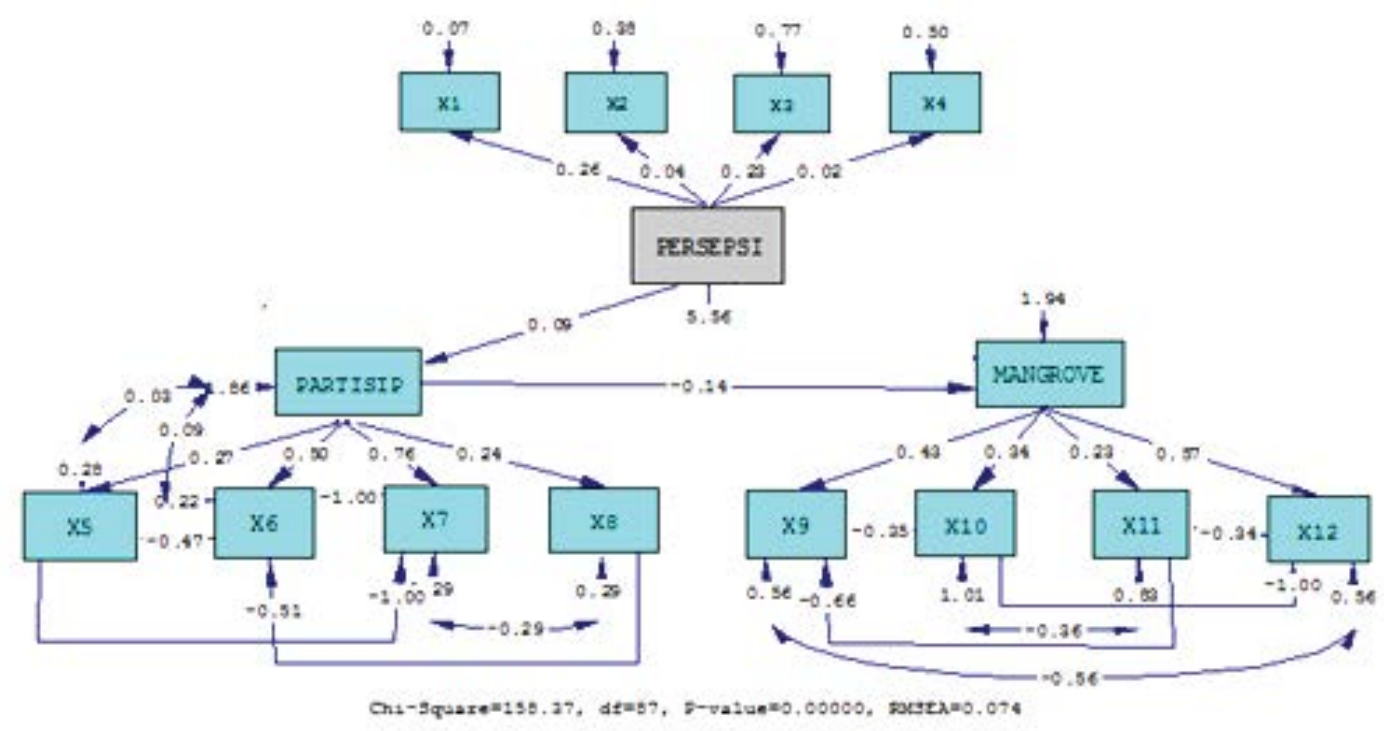

Figure 4: Correlation model of perception, participation and mangrove degradation in Brebes Regency.
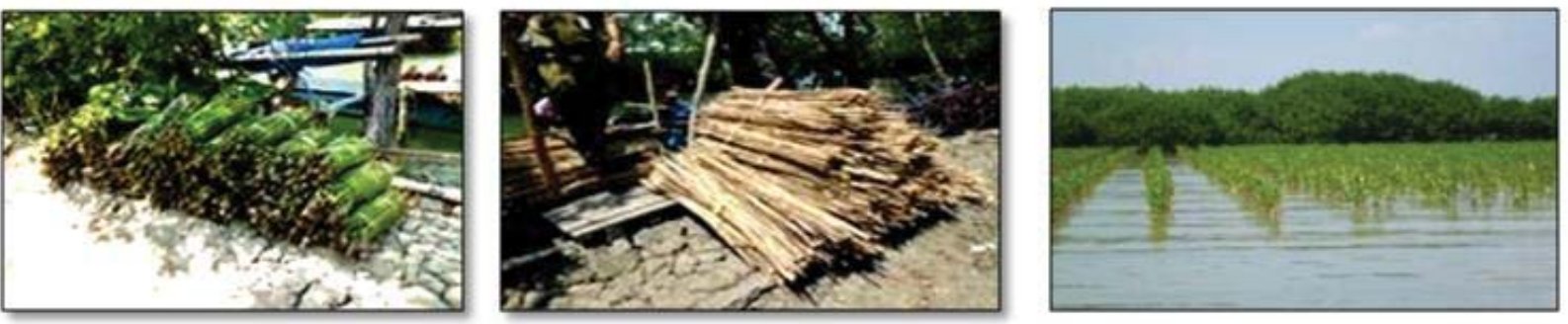

Figure 5: Profagul (mangrove seedlings), ijiran and mangrove reforestation in Kaliwlingi coastal Sub District of Brebes.

coastal, Sub District of Losari has fallen for it was not much stronger to face the wave brunt. This is presumably because the embedding is lacking in, while it is directly facing the Java Sea. Besides breakwater built in the coastal waters tends to be mounted parallel to the coast facing perpendicular wave energy so that the brunt of huge waves breaks down the barrier waves. Similarly, the breakwater of stones piles on the beach of Randusanga-Kaliwlingi Sub District of Brebes. It can not hold the brunt of a wave as shown in Figure 7.

Strategies analysis of management to mangrove degradation in brebes regency: 1 . SWOT analysis

The process and result of handling mangrove degradation have been done in Brebes Regency coastal areas are grouped into SWOT matrix for th eanalysis of strengths, weakness, opportunities and threats as presented in Table 7 .

Based on the calculation on the matrix of internal and external strategies factors, management strategy development of mangrove area policies in Brebes Regency, it is obtained the total value of internal strategic factors (IFAS) of 2.20 and external (EFAS) of 2.05. These values are included in the internal-external matrix of mangrove management strategies development in Brebes Regency, and these are in the position of segment 5. It can be interpreted that the development of mangrove management strategy in Brebes Regency is still likely to be maintained and further developed as presented in Table 8 [28].

Based on the SWOT analysis matrix that has been obtained, the analysis performed to determine the policy strategy that should be done in the framework of the mangrove management areas in Brebes Regency is obtained the ranking strategies of each segment as follows :

a. Rank 1:WO strategy by the number of weighted value of 2.25 which maximizes prevention/reduction of abrasion in a comprehensive manner to stabilize the presence of mangroves by utilizing technological developments related.

b. Rank 2: WT Strategies by the number of weighted value of 2,20 that optimizes the management of mangrove buffer upstream - downstream areas by improving coordination among mangrove agencies.

c. Rank 3 : SO strategy with the weighted sum of 2.05 invaluable empowering potential of community in mangrove management along Brebes coastal area to achieve the funding available regionally, nationally and internationally.

d. Rank 4:ST strategies with the weighted value of 2.00 that minimizes land use change, deforestation and destruction of mangroves 
Citation: Faperi S, haryono S, Hendrarto IB, Radjasa OK .(2015) Management Strategies of Mangrove Degradationin Coastal Areas of Brebes Regency, Central Java, Indonesia. J Coast Zone Manag 18: 401. doi: 10.4172/2473-3350.1000401

to make effective enforcement of mangrove protection.

\section{Analysis hierarchy process (AHP)}

AHP data analysis based on interviews/questionnaire aiming to determine the priority of Brebes mangrove management is done by using Expert Choise V.9 software. AHP process is done through structural hierarchy of a complex problem that is broken down into parts that are smaller according to the characteristics or specific
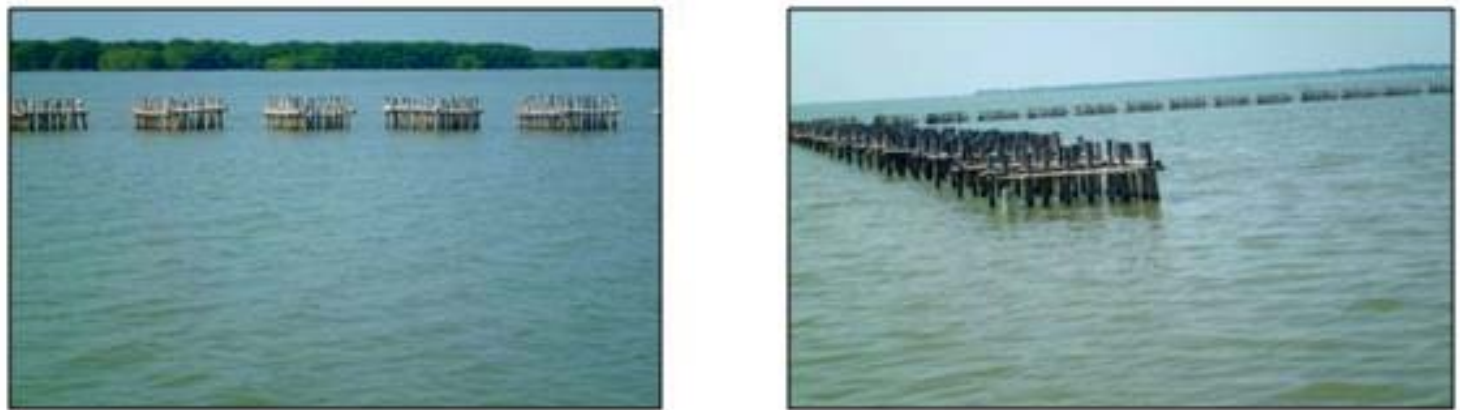

Figure 6: Breaking waves of bamboo in Kaliwlingi coastal waters.
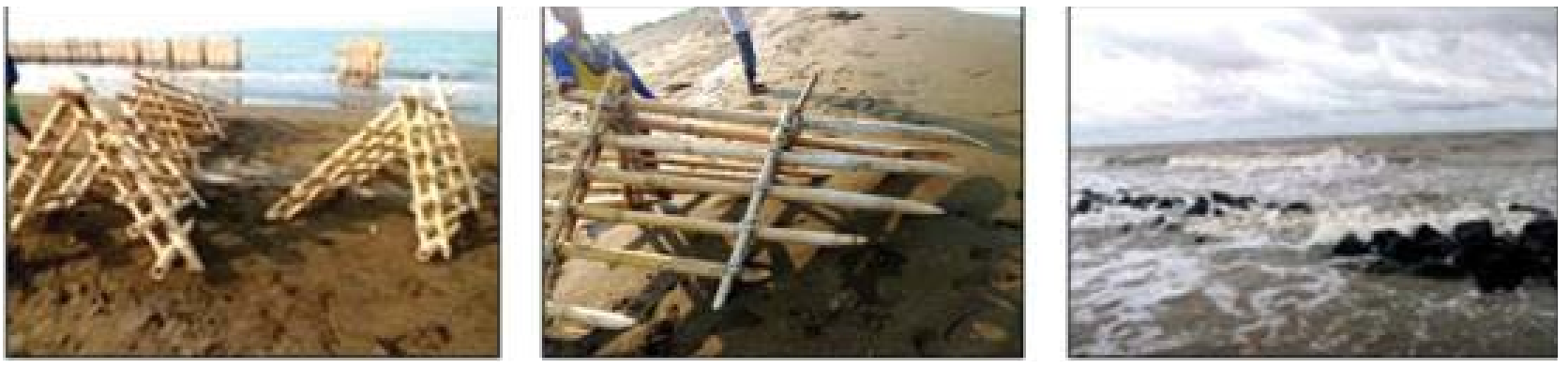

Figure 7: Coastal protective devastated on Karang Dempel sandbars Sub District of Losari and on Randusanga beach Sub District of Brebes.

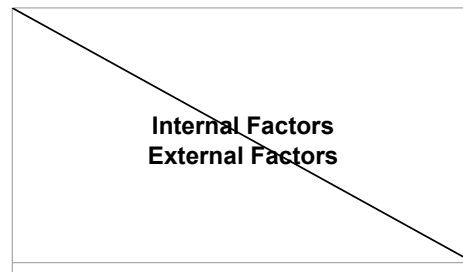

Opportunitie(O)

1. By making the mangrove ecosystem as part of the climate change / environment nationally / globally

2. Availability of mangrove management funds in international, national and regional levels.

3. The development of science

and technology of coatal abrasion management/mangrove management Threats ( $\mathrm{T})$

1. Conversion of mangrove land as residential and industrial areas

2. Utilization of mangrove resources for household use, pharmaceutical and other industries.

3. Management of buffer zones of mangrove ecosystems both upstream and downstream regions is not optimal

\section{Strengths (S)}

1. There is already a mangrove area management regulations from related parties (local government)

2. Brebes Regency has several agencies dealing with the management of mangrove

3. There is a potential coastal communities in mangrove conservation effort

\section{SO Strategy}

Optimizing the community empowerment in mangrove management along the coastal of Brebes Regency by won funding available to regional, national and international $(2,05)$

\section{Weakness (W)}

1. Coordination between mangrove agencies is not optimal 2. Local government attention in the mangrove preservation is uneven across Brebes Regency coastal areas, especially in West Brebes

3. Mitigation techniques of coatal abrasion in Brebes Regency are inadequate and not integrated across regency/provinces other

\section{WO Strategy}

Maximizing of abrasion prevention/reduction in a comprehensive manner to stabilize the presence of mangroves by utilizing related technological developments $(2,25)$

\section{WT Strategy}

Minimizing land conversion, logging and destruction of mangroves with effective enforcement of mangrove protection (2.00)
Optimizing the upstream-downstream area management of mangrove buffer areas by improving coordination among mangrove agencies. $(2,20)$

Table 7: SWOT Interaction Matrix of Brebes Regency mangrove areas management 


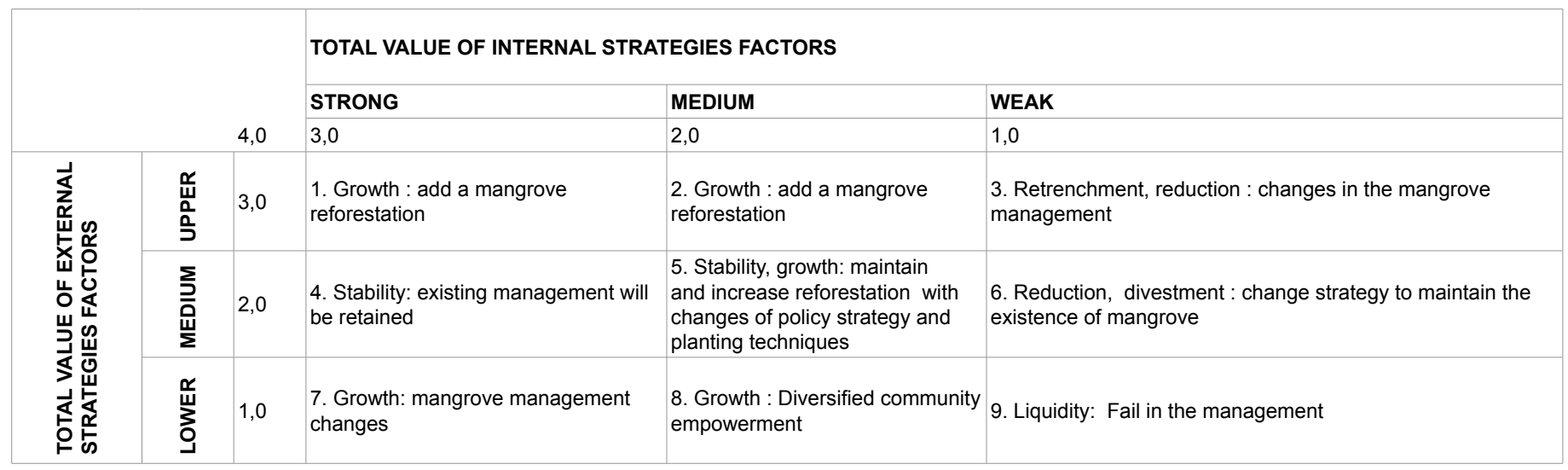

Table 8: Internal - External (IE) matrix in management strategies of Brebes Regency mangrove areas.

amount. Interview/questionnaire is the primary data collection techniques performed to determine what strategy should be carried out by the Brebes Regency Government in defining alternative of mangrove management. Prioritization decision elements is done by making comparisons using a matrix table and analysis of issues raised in the Brebes Regency coastal areas, where the priority terms of problem will be dominating and dominated. Alternative of mangrove management strategies in Brebes coastal areas taken from SWOT analysis results are presented in Figure 8.

The result of a weighted sum of criteria in a hierarchical structure created with Expert Choice V.9 Software. To know the final result of each alternative strategy, calculation is done by counting weight overall or aggregate weights of alternatives toward the existing criteria, from strategy of A, B, C, D and E as shown in Table 9.

From the calculation above, the order of strategic priority to be considered in the mangrove management in Brebes regency coastal areas are:

A. Maintain the existing mangrove vegetation and improve the effectiveness of reforestation of mangrove vegetation.

1. Providing protection for newly planted mangrove seeds in areas prone to abrasion by placing break water/damper waves, APO or concrete buis/polybag in the section dealing with the arrival of sea waves. Preparing the coastal structures (groins, seawall) of massive materials such as large rocks, cast materials focusing on the strength, direction, character, currents of waves and cell sediment in Brebes Regency coastal areas $[28,29]$.

2. Doing reforestation of mangrove vegetation by regarding the balancing technique between the energy of the ocean waves with depth of ijiran embedding as a bound mangrove seeds/profagul). In general, if ijiran is in the form of split bamboo 2-4 and weighs about $250 \mathrm{~g}$, the embedding mangroves ijiran should be done to a depth of more than $1.07 \mathrm{~m}$.

3. Selection of mangrove vegetation types according to the type of soil texture. Based on the type of substrate and the condition of the beach (accretion or erosion), then in accordance with the opinion $[9,30]$, mangrove species that can be planted for mangrove rehabilitation activities are as follows:

a. The beaches experiencing abrasion and has a muddy sand substrate as in stations 1, 2, 3 and 4 in Sub District of Losari until Wanasari was planted with Rhizophora spp. and Avicennia spp. b. The beaches experiencing abrasion and having sand substrate such as at stations 5 and 6 around the estuary of Pemali River in Sub District of Brebes were planted with Rhizophora spp.

4. Selection of the exact location of reforestation, starting from a relatively sheltered from the ocean waves in accordance with zoning program of mangrove conservation in Brebes Regency, which is located in the villages of Randusanga Kulon, Kaliwlingi, Sawojajar, Grinting, Kluwut, Krakahan, Pengaradan, Prapag Kidul, Prapag Lor and Limbangan. Further development of the coastal region of mangrove forest in the coastal areas of Brebes Regency is located along the coast include: Sub District of Losari (Villages of Limbangan, Karangdempel, Prapag Lor, Prapag Kidul and Kecipir); Sub district of Tanjung (Krakahan and Pengaradan Villages); Sub District of Bulakamba (Villages of Grinting, Pulogading and Bangsri); Sub District of Wanasari (Sawojajar Village); and Sub District of Brebes (Kaliwlingi and Randusanga KulonVillages).

B. Increasing the empowerment of mangrove potential areas through productive activities that increases the added value for improving the welfare of local communities while conserving the mangrove/coastal resources.

1. Marine aquaculture: Planning and site selection of marine culture should consider the limiting factors, which include site protection and turbidity waters [31]. Based on the site protection factor, Brebes coastal areas are categorized into protected, less protected and unprotected areas. Clear waters are more than $2.5 \mathrm{~km}$ from the shoreline, this is marked with the number of step chart in this area, especially in the northern Gulf of Bangsri. Marine culture types that are allowed to be cultivated: (1) sea cucumbers, (2) oyster, (3) fish with floating net and (4) seaweed. Based on the identification of its carrying capacity, then the location of marine aquaculture is suggested in the coastal waters of Kaliwlingi and Sawojajar Villages, Sub District of Brebes, and the waters in front of the Karang Dempel Village in Sub District of Losari. The location which is still possible for marine aquaculture activities are coastal waters of Bangsri, Pulogading, Grinting, Kluwut, Krakahan, Pengaradan, Prapag Lor, Prapag Kidul and Limbangan Villages Sub District of Losari, Tanjung and Bulakamba up to $1 \mathrm{~km}$ from the coastline. The areas not recommended for the location of marine aquaculture are the coastal waters of Randusanga Kulon and Randusanga Wetan Villages in Brebes Sub District.

2. Aquaculture pond (brackish water): Within the plannned development of the ponds area in Brebes Regency coastal areas, it is 
Citation: Faperi S, haryono S, Hendrarto IB, Radjasa OK .(2015) Management Strategies of Mangrove Degradationin Coastal Areas of Brebes Regency, Central Java, Indonesia. J Coast Zone Manag 18: 401. doi: 10.4172/2473-3350.1000401

\section{Mangrove degradation in Brebes Regency coastal areas}

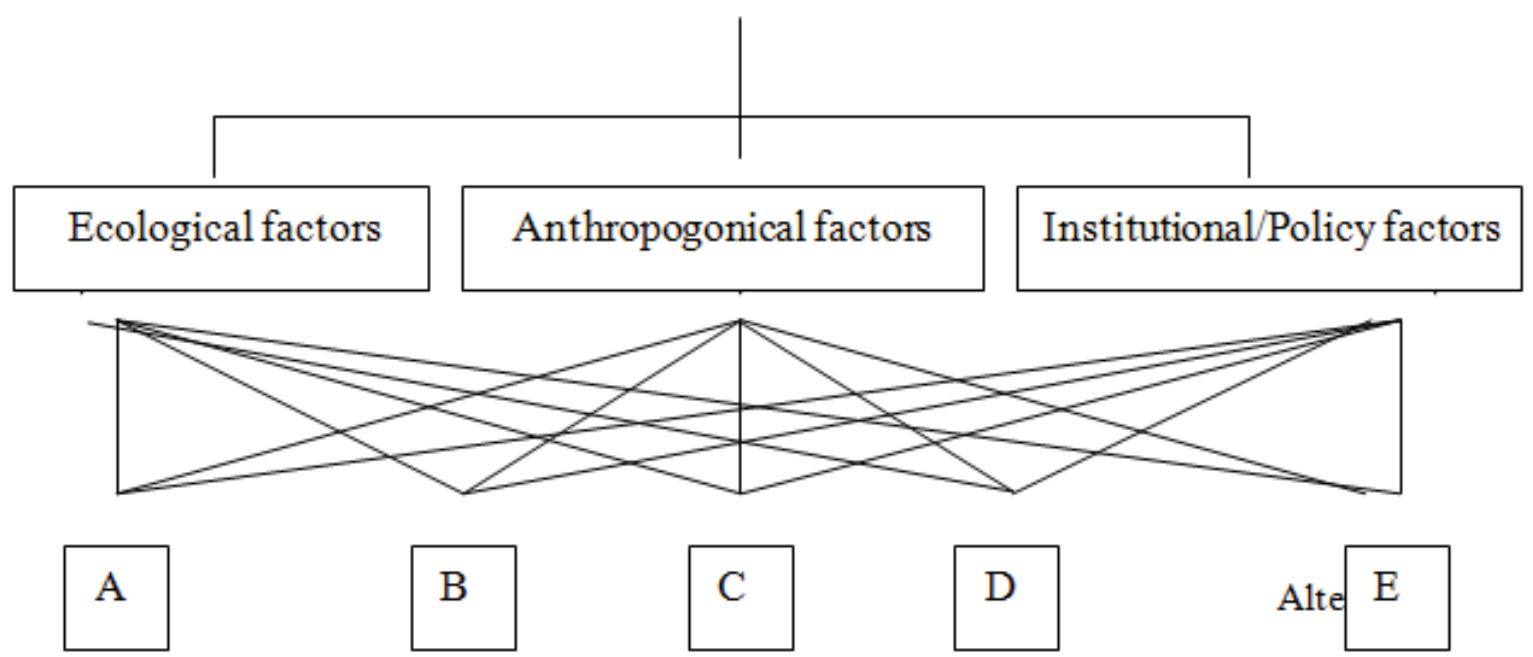

Figure 8: Decision alternative mangrove management strategies in Brebes Regency coastal area.

\begin{tabular}{|c|c|c|}
\hline No & Criteria alternative & Weighting \\
\hline 1 & A strategy & $\mathbf{0 , 3 0 1}$ \\
\hline 2 & B strategy & 0,148 \\
\hline 3 & C strategy & 0,137 \\
\hline 4 & D strategy & 0,215 \\
\hline 5 & E strategy & 0,199 \\
\hline
\end{tabular}

Iconsistency Ratio: 0,05Source: The results processed, 2013

Table 9: Weight of alternative aggregate/priority of the selected strategy.

important to note the limiting factors such as slope, soil texture and water quality. Based on the condition of the beach slope, texture and quality of the coastal waters, the coastal areas are suitable for aquaculture activities including ponds in Kaliwlingi and Sawojajar Villages (Sub District of Wanasari), Grinting and Krakahan Villages (Sub District of Tanjung).

3. Capture fisheries: In accordance with the Decree of the Minister of Agriculture No. 392 / Kpts / IK.120 / 4/1999, based on the authority of local governments by $1 / 3$ area of provincial jurisdiction or 4 miles, fisheries catchment areas in the water Brebes Regency are included in the IA path (small scale) and IB (medium scale).

C. Making the implementation of regulations more effective and optimalizing the role of relevant agencies, civil society organizations, and the participation of local communities in conserving the mangrove areas and coastal resources and develop it.

1. Enforcement of rules/sanctions for loggers/burner of mangrove vegetation as happened in the coastal of Randusanga Kulon Village, Sub District of Brebes, Kaliwlingi Village Sub District of Wanasari and Krakahan Village Sub District of Tanjung.

2. Increasing empowerment mangrove supervisor group according to Soraya, et al. in Eastern Brebes region and the establishment of mangrove supervisor group in central and western area of Brebes Regency [32]. Mangrove supervisor group of the community in the Eastern Brebes region, namely Wana Segara group is relatively existing. The group can be used as a reference for the establishment and empowerment of mangrove supervisor groups in the Western and Central Brebes region [33].

3. Providing incentives for people who preserve the mangroves, as well as crab seekers and beaches fishermen at locations near the mangrove forest. The incentives are expected to be emotional attachment to preserve the mangroves, especially the newly planted mangrove vegetation and prone to collapse. It is intended to foster self-awareness of coastal communities in mangrove preserving participation [34,35].

D. Strengthening institutional systems, both government and public institutions in the management of mangrove forests for short, medium and long term.

1. Synchronizing the area of reforestation and mangrove monitoring responsibilities among agencies. This is to overcome the ever arising problems, namely the overlapping of reforestation location and its monitoring at locations relatively easy to reach like the coastal areas of Eastern Brebes. On the other hand, the less affordable areas can not be 
Citation: Faperi S, haryono S, Hendrarto IB, Radjasa OK .(2015) Management Strategies of Mangrove Degradationin Coastal Areas of Brebes Regency, Central Java, Indonesia. J Coast Zone Manag 18: 401. doi: 10.4172/2473-3350.1000401

handled optimally.

2. Matching the perception on mangrove preservation in the conflict of interest according to Gumilar [36], such as mangrove logging in Krakahan Village Sub District of Tanjung for widening channel of water supply of salt manufacture. Those problems can actually be avoided although it needs an additional budget for land acquisition of widening of drains.

E. Increasing the counseling activities/community empowerment, including the youth in line with the importance of mangroves for coastal resource conservation.

1. Involving young people (kindergarten studens until college students) in activities such as mangrovelove through: inserting mangrove ecosystems as part of a lesson in school, beach tent, participation in mangrove reforestation, competition of mangrove utilization as food products besides keeping maintaining its sustainability.

2. Increasing the intensity of counseling on the importance of coastal/mangrove resources conservation through radio, TV and other information media, especially on special occasions endear the young generation.

\section{Conclusions and Recommendations}

1. The density and degradation of mangroves in Brebes coastal area is in very rare range (badly degradation) to moderate (medium degradation) except in the east coast of Brebes region in Kaliwlingi Village, Sub District of Brebes which has a category of tightly density level (good) because it is an area of mangrove reforestation. Mangrove areas in Brebes Regency coastal areas are reduced with the rate of reduction of 68.46 ha./year.

2. Ecological and anthropogenic factors jointly affect the mangrove degradation in Brebes Regency coastal areas, but the influence of ecological factors (abrasion) tends to be more dominant

3. The condition of mangrove forests in Brebes Regency coastal areas is relatively still possible to be maintained and developed by the more effective strategy.

\section{Recommendation}

In dealing with degradation of mangroves in Brebes coastal areas, the orderly strategic priorities should be considered as follows:

A. Improving the mangrove area protection from sea waves/ abrasion and developing it through the retaining/optimal breakwater.

B. Empowering the mangrove areas potential through productive activities that increase the added value for improving the welfare of local communities and keeping conserving the mangrove/coastal resources.

C. Making the implementation of regulations and optimalizing the role of relevant agencies, civil society organizations, and the participation of local communities in conserving the mangrove areas and coastal resources.

D. Strengthening the institutional systems, both government and public institutions in the management of mangrove forests for short, medium and long term.

E. Increasing the counseling activities/community empowerment, including the youth in line with the importance of mangroves for coastal resource conservation.

\section{Acknowledgements}

The scientific article is part of the dissertation in The Doctoral Program of Coastal Resources Management, Diponegoro University, Semarang. The main author would like to thank to Rector of Diponegoro University; Dean of Fisheries and Marine Science Faculty - Diponegoro University; Chairman, Secretary and all the Lecturer of Coastal Resource Management Doctoral Program, Diponegoro University; Promoter and Co - Promoter along with all of Examiners Dissertation.

\section{References}

1. Mclvor A, Möller I, Spencer T, Spalding M (2012) Reduction of Wind and Swell Waves by Mangroves. Natural Coastal Protection Series; 27

2. Kustanti A, Nugroho B, Darusman D, Kusmana C (2012) Integrated Management of Mangroves 2012 in Lampung Mangrove Ecosystem Centre (LMC) East Lampung Regency, Indonesia. Journal of Coastal Development 15: 209- 216.

3. Department of Marine and Fisheries of Central Java Province (2012) Coastal Planning and Zoning Small Islands Central Java 135.

4. Department of Fisheries and Marine Brebes (2008) Coastal Spatial Planning of Brebes Regency 56.

5. Onrizal (2010) Cover Change of Mangrove Forest in the East Coast of North Sumatra. Journal of Biol Indon 6: 32-38.

6. Marfai MA (2011) The hazards of coastal erosion in Central Java, Indonesia: An overview. Malaysian Journal of Society and Space 7: 1-9.

7. Poedjirahajoe E (2007) Dendogram of Mangrove Growth Zoning based on Habitats in the area of Coastal Rehabilitation in Western-North Central Java. Journal of Forestry Science Faculty of Forestry, Gadjah Mada University 1 : $10-21$.

8. Kusmana C (2005) Mangrove in Effort to Handle Abrasion and Coasta Management. Sea Partnership Program Workshop, sub RC West Kalimantan, Pontianak

9. Bengen DG (2002) Technical Guidelines of Introduction and Management of Mangrove Forest. PKSPL-Bogor Agriculture Institute. Bogor.

10. Muhamadi E, Susilo Aminullah B (2001) Dynamic Systems Analysis of Environmental, Social, Economic and Management. Centre for Policy Studies and System Dynamics, UMJ Press Publishers. Jakarta. 415.

11. Ghozali I, Fuad (2008) Structural Equation Modeling - Theory, Concepts and Applications with Lisrel 8.80 Program, Second Edition. Publisher Agency Diponegoro University. Semarang. 380.

12. Rangkuti F (1999) SWOT Analysis: Technique Dissecting the Business Case Gramedia. Jakarta. 187.

13. Saaty TL (1993) Decision Making for Leaders, Analytical Hierarchy Process for Decision Making in Complex Situations. Education Institution and Development Management- Gramedia, Jakarta 268.

14. Jeyanny V, Azian M, Fakhri MI, Wan Rasidah K, Suhaimi WC (2012) Shoreline retreat of a degrading mangrove forest in Sungai Besar, Selangor, Malaysia. ISME/ GLOMIS Electronic Journal 10: 19-27.

15. Hidayah Z, Wiyanto DB (2013) Analysis of Temporal Changes in Mangrove Forest Area in Sidoarjo. Journal of Sustainable Earth 13: 318-326.

16. Ontorael R, Wantasen US, Rondonuwu AB (2012) Conditions of Ecology and Mangrove Resource Utilization in South Tarohan Village, South Beo Sub District, Talaud Islands Regency. Platax Scientific Journal 1: 27-34.

17. Gardel A, Gensac E, Anthony EJ, LeSourd S, Loisel H, Marin D (2011) Waveformed mud bars: Reviews their morphodynamics and role in opportunistic mangrove colonization. Journal of Coastal Research 11: 84-87.

18. Tarin BC (2007) Change of Cisadane Coastal Shorelines from Tanjung Pasir to Saban Swamp, Banten Province. Makara Science Journal 11: 49-55

19. Dantas STPL, Amaro VE, Costa BCP (2011) Mangrove Reforestation as Mesotidal Coastal Protection and Clean Development Mechanism on MacauSerra Oil Field, Potiguar Basin, Northeast Brazil. Journal of Coastal Research 11: 68-71.

20. Ghozali I, Fuad (2008) Structural Equation Modeling - Theory, Concepts and Applications with Lisrel 8.80 Program, Second Edition. Publisher Agency 
Citation: Faperi S, haryono S, Hendrarto IB, Radjasa OK .(2015) Management Strategies of Mangrove Degradationin Coastal Areas of Brebes Regency, Central Java, Indonesia. J Coast Zone Manag 18: 401. doi: 10.4172/2473-3350.1000401

Page 12 of 12

Diponegoro University, Semarang 380.

21. Fiazia NA (2006) Mangrove Community Structure and Its Implications on Coastal Rehabilitation in Brebes Regency, Central Java. Department of Water Resources Management, Faculty of Fisheries and Marine Science, Bogor Agricultural Institute, Bogor.

22. Jusoff K, Dahlan D (2008) Managing Sustainable Mangrove Forests in Peninsular Malaysia. Journal of Sustainable Development 1: 24-31.

23. Setiawan AD, Winarno K (2006) Problems of Mangrove Ecosystem Conservation in Rembang Coastal Regency. Journal of Biodiversity 7: 159-163

24. Amri A (2005) Community Participation in Rehabilitation, Conservation and Management of Mangroves: Lessons from Coastal Areas of South Sulawesi, Indonesia. African Study Monographs 29: 19-30.

25. Yulistiyanto B (2009) Mangrove with waves breaking tool (APO) as the Coastline Protection, Proceedings of the National Seminar on Participatory Water Resources Management in Anticipation of Global Climate Change Impacts 10.

26. Petra JL, Sastrawibawa S, Riyantini I (2012) The effect of Mangrove Density on The Rate of Sediment Transport in Karangsong Sub District, Indramayu Regency. Journal of Fisheries and Marine Sciences 3: 329-337.

27. Siswanto AD (2011) Distribution Study of Bottom Surface Sediment Substrate in Bangkalan Coastal Regency. Embryo Journal 8: 3-6

28. Agency of Region Development and Planning, Central Java Province (2012) Model Formulation and Development of Mangrove.

29. Hidayat N (2006) Marine and Coastal Construction as Coastal Protection
Alternative SMARTek Journal 4: 10-16

30. Gunarto. 2004. Conservation of Mangrove as Biological Resources Support of Coastal Fisheries in Tongke-Tongke, South Sulawesi. Journal of Agricultural Research 23: 15-21.

31. Kadarusman, Razak AD (2004) Interconnectivity of Mangrove Management for System of Sustainable Wanamina. Journal of the Academy of Fisheries Institute Sorong 2: 16 -25.

32. Soraya D, Suhara O, Taofiqurohman A (2012) Changes in Coastline Damage Due Mangrove in the District and Sub-District Blanakan, Legon Kulon Subang. Journal of Fisheries and Marine Resources 3: 355-364.

33. Agency for the Assessment and Application of Technology (2001) Development of Land Cover and Land Use Brebes Region, Central Java. Natural Resource Inventory Technology. Agency for the Assessment and Application of Technology, Jakarta.

34. Hanifa A, Pribadi R, Nirwani (2013) Economic Valuation Study of Mangrove Forests in Banggi Market Village, Sub District of Apex, Apex District. Journal of Marine Research 2 : 140-148.

35. Astra US, Sabarini EK, Harjo AM, Maulana MB (2014) Community Involvement in Coastal and Marine Area Management; Case Study: Coastal Protection Zone Timbulsloko Village, Sayung, Demak. International Wtlands of Indonesia, Bogor 34.

36. Gumilar I (2012) Participation of Coastal Community in Management of Sustainable Mangrove Forest Ecosystem in Indramayu. Aquatics Journal 3: 198-211. 